ADDIN, Volume 10, Number 2, August 2016

\title{
CASH ENDOWMENT (WAKAF TUNAI) DEVELOPMENT IN THE ERA OF THE ASEAN ECONOMIC COMMUNITY
}

\section{Onny Medaline}

Pembangunan Panca Budi University Medan, North Sumatera, Indonesia

omed_line@yahoo.com

\begin{abstract}
The constitution No. 41 of 2004 has expanded the objects to be endowed, in general it's not only the unmoving objects, but the moving object also becomes the object of endowments objects such as cash endowment (money). The management of endowment gets the understanding shift slowly, which is in the narrow sense as an entity limited endowments of worship only, but has now showed as the endowment understanding in the productive manner for the management of endowment property. So the system of cash endowment management needs the management models as the operational standard to use the funds maximally. In this era of ME $A$, cash endowment is expected to be one of the instruments to assist the government in the financial sector to develop the vital sectors that grow through existing Small and Medium Business (SMB) in the community. Instead, ME $A$ is a challenge for modern development of cash endowment to be Islamic institutions be able to become a source of capital and investment for growth economy of community.
\end{abstract}

Keyword: Cash Endowment, ASEAN Economic Community. 


\section{Abstrak}

Undang-undang Nomor 41 Tabun 2004 telab memperluas objek wakaf, secara umum, tidak hanya berupa benda-benda tak bergerak, objek bergerak juga dapat menjadi objek wakaf seperti uang tunai. Pemahaman tentang pengelolaan wakaf perlahan mengalami pergeseran, yang dalam arti sempit wakaf terbatas sebagai entitas ibadah saja. Sekarang pemahaman tentang wakaf lebih menunjukkan upaya yang produktif dalam pengelolaan properti wakaf. Jadi, sistem manajemen wakaf tunai membutubkan model manajemen yang memiliki standar operasional dalam menggunakan dana secara maksimal. Di era Masyarakat Ekonomi Asean (MEA), wake af tunai diharapkan menjadi salah satu instrumen untuk membantu pemerintah di sektor keuangan dalam mengembangkan sektor penting yang berkembang melalui bisnis masyarakat menengah dan kecil. Di sisi lain, MEA dapat menjadi tantangan bagi perkembangan wakaf modern untuk menjadi institusi Islam yang dapat menjadi sumber modal dan investasi untuk pertumbuban ekonomi masyarakat.

Kata Kunci: Wakaf Tunai, Masyarakat Ekonomi Asean.

\section{A. Introduction}

AEC or abbreviated as MEA could be interpreted as a form of economic integration of ASEAN economy, which means all the countries located in Southeast Asia (ASEAN) implements a system of free trade. Indonesia and all other ASEAN countries (9 countries) have agreed on the MEA agreement or in English as ASEAN Economy Community or AEC. The purpose of the establishment is to bring about an economic order that is free and open in flow of goods, services, investment and capital flows, which in turn is expected to improve the welfare of all members of ASEAN so it can face the competition in the regional and global scope.

Several studies mention the strategies that can be used in order to compete in the free market, such as further improve the import-export checks clearly, the need of political stability, the government must be clean from the corruption, the 
social order as well as their technological innovation and the availability of adequate infrastructures. However, to achieve all it is also required the human resources who are experts in specific areas, improving education, and utilizing the existing natural resources to improve the management of the raw materials production so the Indonesian people have adequate economic welfare standards.

Based on these conditions, in fact Indonesia still has the other potential that is not optimized in the aspects of resource endowments. The existence of endowment land in Indonesia counted up to 2014, there are 191,581 locations (one bundred and ninety one thousand five hundred and eighty one location) with an area of 21.251,22 hectares ${ }^{1}$ covering (twenty-one thousand two bundred and fifty-one point twenty two hectares) has a great potential to reach the purpose of endowments that is for the welfare of the people. But nazhir (the recipients of endowments) do not have the innovative ideas about how to process and manage the productive endowments. The majority of the nazhir only focus on the construction of places of worship, cemeteries and other public facilities that tends to be unproductive. Furthermore, endowments not only related to issues of spirituality and religion, but also an important issue that can affect the economic, political, community, education, and social development. Therefore, the productive management of a good management system becomes very important to do in order to realize some of these aspects, and one of them is the economic aspect. ${ }^{2}$

Although the existence of endowment does not give the direct impact on strengthening the MEA passes that have been launched in 2015 ago. But at least the endowments in the era of modern MEA must be managed modernly and professional

${ }^{1}$ http:// simbi.kemenag.go.id/siwak/index.php, accessed at June 23, 2016.

${ }^{2}$ Chowdury M. S. Rahaman, 2012, "Problems Of Waqf Administration and Proposals for Improvement: A Study in Malaysia", Journal of Internet Banking and Commerce, Vol. 17, No. 1, April 2012. 
towards the productive endowments. So the endowments do not only touches the social issues but it should be managed in the productive manner that led to the economic development of the people to build a civilization. Based on the explanation, it will be described in the discussion of the form of cash endowment management arrangement productively in an era of MEA.

\section{B. Discussion}

\section{Basic Law of Wakaf}

Related to these issues, in the Koran there are no clear provisions governing this issue. But the Koran command to do good deed can be used as a common foundation for the practice of endowment. Most jurists associate legal basis endowment by doing good command of al-Qur'an contained in Surah alMa'idah [5]: 2 which means that reads, “... And please-menolonglah you in the (working) virtue and piety ..." .Ayat advocates to come together to do good in all forms of good deeds. No good deeds that are eternal and uninterrupted, there is also the last for a certain period then ended, and there is also a direct utilized. On the other hand, there is goodness that leads to a specific person, such as a particular group of people with specific properties, or for a specific purpose without looking at people who want to use it. ${ }^{3}$ And Surat al-Ma'un [107]: 7 are set, "and reluctantly (belp with) useful stuff'. That is, God gave the threat of hell to the people who have bad properties, which were described in this paragraph, they even hold items needed others when they themselves do not need them. ${ }^{4}$

Most other jurists associate legal basis endowments with verses from the Qur'an which govern the believers to do good, which is contained in the following verses: ${ }^{5}$ (a) al-Quran surat alBaqarah [2]: 267 commands: "O ye who believe, spend in (in the way

\footnotetext{
${ }^{3}$ Munzir Quhar, Manajemen Wakaf Produktif (Jakarta: Khalifa, 2004), p. 136.

${ }^{4}$ Ibid.

${ }^{5}$ Ahmad Azhar Basyir, 1987, Hukum Islam tentang Wakaf, Ijarah, Syirkah, Al-Ma’arif, Bandung, hlm. 5. Lihat Rachmad Djadmika, Rachmad Djadmika, Hukum Perwakafan Tanah
} 
of Allah) of the fruit of your efforts are good and some of what we remove from the earth for you. And do not choose a bad-bad and then you spend on him, whereas you are not willing to take it, but with squinted against him. And know that Allah is Rich, the Praised ". (b) al-Qur'an letter of Ali 'Imran [3]: 92 decisive: "You never come to worship (perfect), before you spend most of that which ye love. And whatever you spend, Allah knows “. (c) of the Qur'an Surat al-Haji [22]: 77 commands: "O ye who believe, ruku'lah ye, ye bowed, worship your Lord and did according virtues so that you get a victory."

The verses of the Qur'an that does not directly describe the endowment, but the jurists associate it as the basis of the common law of endowment. This is due to these verses encourage people of faith to do good through possessions belong to. One of the verses about the act of kindness that is recommended is through endowments.

Besides the common basis of some of the preceding paragraph, there is also a tradition in some of them, the most famous saying of the Prophet (hadis) contains about the endowment is a hadith that tells the endowment from Umar bin al-Khattab.

And from Ibn Umar, that Umar never get a piece of land from the land of Khaibar, then he asked me (to the Prophet): Messenger of Allah, I got a piece of land in Khaibar, a treasure that has never Eureka altogether better for me than the land, then what he would you say to me? Then He said, "if you will, resist the bilt and sedekabkan results ". Then Umar menyedekabkan the condition may not be sold, should not be granted, and should not be inherited, which is for poor people, for the immediate family, to liberate a slave, to entertain guests and for those who run out of stock in the journey (Ibn sabil) and innocent people who take care of it to take part in a reasonable manner and to feed (to his family) on the condition that should not be proprietary and in the history of saying: the condition is not controlled substantially (hadith narrated by the group). ${ }^{6}$

Milik di Indonesia (Bandung: t.p., 1983), hlm. 4. Lihat Mohammad Daud Ali, Mohammad Daud Ali, Sistem Ekonomi Islam Zakat dan Wakaf (Jakarta: UI-Press, 2012), p. 80-81.

${ }^{6}$ Uswatun Hasanah, Peranan Wakaf dalam Mewnjudkan Kesejabteraan Sosial (Studi Kasus Pengelolaan Wakaf di Jakarta Selatan), Disertasi, Program Pascasarjana Institut Agama Islam Negeri (IAIN) Syarif Hidayatullah, Jakarta, 1997, p. 6. 
The endowment conducted by Umar bin Khattab is then followed by the companions of the Prophet Muhammad that others such as Usman bin Affan, Abu Talhah, and others. Endowments have been done by the companions then followed by Muslims today in the whole world, particularly in Islamic countries or countries that are predominantly Muslim society such as Egypt, Saudi Arabia, Jordan, Syria, Pakistan, Turkey, Indonesia, and others. ${ }^{7}$

Ustman bin Affan, has also dontaed his property when respond to the call of the Prophet to purchase Raumah wells and also when he became the caliph, as Tirmidhi and Nasa'i narrated from Abu Salamah ibn Abdurrahman and Ahmaf bin analogy. In most of its history, the Prophet said, "Whoever buys it (well Raumah), and draw together the Muslims in the wells it well, then he will get to heaven". ${ }^{8}$ Imam Muslim and the author of As-Sunna also narrated the hadith of Abu Hurairah that the Prophet said "If the child adam died, then terputuslab all bis deeds except for three cases: shadaqah jariah, useful knowledge, children who pray for their parents." In the history of Ahmad Abu Umamah, "And someone who menyadaqabkan treasure and reward go together with the passing shadaqabnya." "The scholars interpret that referred to as-sadaqah al-jariah on the hadith is endowment.

In addition based on the Qur'an and the Hadith, the scholars unanimously (ijma') received endowments as one charity that is prescribed in Islam. No one can negate and reject the practice of the endowment in Islam as endowment has become the practice of continually used and practiced by the companions of the Prophet and the Muslims since the beginning of Islam until now.

\footnotetext{
${ }^{7}$ Ibid.

${ }^{8}$ Mundzir Qahar, Manajemen Wakaf Produktif., p. 78

${ }^{9}$ Ibid.
} 


\section{Understanding Endowment}

The endowment property as a form of spending virtue streets, an alternative offered by Islam as a means to draw closer to God. Wakaf called al-habs (holding), in the language of al-habs means al-sijn (prison), silent, prevent, hindrance, obstacle, "custody" and security. Combined ahbasa word (alhabs) with al-mal (property) means endowment (abbasa al-mal). ${ }^{10}$ Nomenclature endowments in the books of hadith and figh is not uniform. Al-Syarkhasi in the book of al-Mabsut provide endowment nomenclature with al-Awqaf; Imam al-Shafi'i in al-Umm provide endowment nomenclature with al-Ahbas and even Imam Bukhari hadith include about endowments with nomenclature Kitab al-Washaya. Therefore, technically, endowments referred to by al-abbas, shadaqah jariah, and alAwqaf. ${ }^{11}$ The diversity of nomenclature endowments because there was no word wakaf explicitly in the Qur'an and Hadith. This shows that the region ijtihadi in the field of endowments greater than tawqifi region. Nevertheless the results of human ijtihad can not be equated with a law that is human thought as such. Ijtihad has different methods by thought (free-liberal) humans in shaping the law because in the classical theory (fiqib) 12 determined how methods can be explained to dig all stems from the laws of sharia.

The terminology of endowment or in Indonesian called wakaf, derived from the Arabic verb waqafa means stopping,

${ }^{10}$ Ahmad Rofiq, Hukum Islam di Indonesia, Ahmad Rofiq, Hukum Islam di Indonesia (Jakarta: Raja Grafindo Persada, 1997), p. 490.

${ }^{11}$ Jaih Mubarok, Wakaf Produktif, Jaih Mubarok, Wakaf Produktif (Bandung: Simbiosa Rekatama Media, 2008), p. 10.

${ }^{12}$ Lihat Abdul Ghofur Anshori dan Yulkarnain Harahab, 2008, Hukum Islam Dinamika dan Perkembangannya di Indonesia, Kreasi Total Media, Yogyakart., hlm. 20. Ushul merupakan bentuk jamak ashlmemiliki arti sebagai dasar (fundamen) yang di atasnya dibangun sesuatu. Jika dihubungkan dengan fikih maka ushul fikih memilik pengertian sebagai dalil-dalil fikih. Dengan kata lain ushul fikih adalah kaidah-kaidah yang menjelaskan tentang cara (metode) pengambilan (penggalian) hukum-hukum yang berkaitan dengan perbuatan manusia dari dalil-dalil syar'i. 
standing still or hold anything. ${ }^{13}$ In the literature, synonyms wakaf is habs. ${ }^{14}$ Both the noun derived from the verb waqafa and habasa, means to stop, detain. The plurality is Awqaf for Awqaf and ahbas to habs. The words hold endowments detained because of damage, sale, and all actions that are not consistent with the objectives of wakaf. The word "resist" as well as the benefits and the results were detained and forbidden for anyone other than those included entitled to the endowment.

The scholars have different opinions about the meaning of the term endowments and provide definitions that vary according to differences in the school which they profess, both in terms of prevalence and uncommon, terms of approach in the issue of wakaf or wakaf property owner's position after being donated. There was also a difference in perception within the procedures of the wakaf. ${ }^{15}$ Here are some opinions of the scholars who define endowments, such as Imam Nawawi who bermadzhab Shafi'i defined wakaf as "detention treasure that can be used while maintaining the integrity of the goods, regardless of intervention wakif or the other, and the result is channeled for the benefit solely to taqarrub (closer) to Allah. The definition of the Shafi'i sect mentioned above, reinforce the ownership status of wakaf property, endowments declared valid if the ownership was shifted from the original property owners to Allah. ${ }^{16}$ With the understanding that diwakafkan treasure would belong to the people, no longer belongs to the person donating, then severing the relationship of people donating his wealth by diwakafkannya. According to Abu Hanifah endowments are immovable termination of ownership wakif legally and

${ }^{13}$ Mohammad Daud Ali, Op Cit., p. 80

${ }^{14} \mathrm{Ibid}$.

${ }^{15}$ Muhammad Abid Abdullah Al-Kabisi, Mubammad Abid Abdullah al-Kabisi, Hukum Wakaf: Kajian Kontemporer Pertama dan Terlengkap Tentang Fungsi dan Pengelolaan Wakaf serta Penyelesaian atas Sengketa Wakaf (Jakarta: Penerbit Iiman kerja sama dengan Dompet Dhuafa Republika, 2004), p. 38.

${ }^{16} \mathrm{Ibid}$. 
penyedekahan benefits for the public interest. Therefore the items of donated (diwakafkan) should not be separated from the ownership and legitimate wakif for wakif pulled again and allowed to sell it. ${ }^{17}$ Hence, according to followers of sects Hanifah, that endowment remains the property wakif, this is to explain that the endowment is not luzum (must) and being allowed to revoke endowments wakif back. ${ }^{18}$

Indeed, there are differences of opinion on the schools that exist, it is more to the placement and control of wakaf property, the majority opinion states remain in control of wakaf property wakif. While most other opinion, stated the release of ownership rights in perwakafan. But both these opinions to stick to the principle that the property of the wakaf should be maintained its existence with the aim to be managed and taken advantage for the benefit of the people, so the door kindness will not be closed because the Islamic law has been opened by issuing the teachings of a general nature invite to goodness.

Therefore, the provisions of Endowment in Indonesia do not take particular as a School of Law Schools officially adopted by the state, the development of Islamic law in the field of zakat and wakaf is the background of diversity of schools contained in Islam.Even though Indonesian Muslim community largely follows the Shafi, but in the context and content regulation of The endowment (Perwakafan) and Zakat do not happen the stiffness schools let alone "syafi'ioriented"; it dynamically forward the "maqashid sharia" (Islamic law purposes) as a criterion. It was seen from the discourse of jurisprudence applied Alms enterprise, income zakat profession, endowment money, endowments within a certain period, and the other to

\footnotetext{
${ }^{17}$ Dalam Uswatun Hasanah,Peranan Wakaf., p. 30

${ }^{18}$ Mundzir Qahar, Manajemen Wakeaf Produktif., p. 48.
} 
accommodate the treasures of Islamic law which is very rich in ijtihad, istinbath and istihsan. ${ }^{19}$

\section{The Understanding of Wakaf Contemporary}

The history of endowments have played a very important role in community development, management of wakaf gradually shows the positive effects towards better management. Scientists continue to conduct studies on strategic management of wakaf hoping that in the future endowments to function properly. A shift and a change in the strict sense of understanding wakaf endowments as the entity that sees special worship alone, has now been demonstrated understanding of endowments productively towards the management and utilization of wakaf property.

According to Tata Fathurohman, Wakaf is a legal act of wakif to hold his property, either temporarily or permanently, used repeatedly in the public interest and in particular in accordance with the principles of Islamic Shariah. This understanding includes many forms of property that may be used as endowments, both in the form of immovable such as land, or moving objects such as money, precious metals, intellectual property rights, and moving objects other in accordance with the provisions of the Sharia and the provisions of the legislation in force.$^{20}$ From this sense, the use of wakaf property covers a very broad field of activity, both direct utilization as used for mosques and schools or utilization is not directly by giving the management of wakaf property productively to the parties entitled to receive. Utilization is also indicated in general such as an alternative, both to help the poor and in particular by means wakif designate certain parties entitled to receive the results.

\footnotetext{
${ }^{19}$ http:/ / www.bi.go.id, M. Fuad Nassar, "Pengembangan dan Implementasi Zakat Wkaf di Indonesia”. accessed at August 17, 2015.

${ }^{20}$ Tata Fathurrohman, Wakaf dan Usaha Penanggulangan Kemiskinan Tinjauan Hukum Islam dan Perundang-undangan Indonesia, Disertasi, Program Pascasarjana, Universitas Indonesia, Jakarta, 2006,
} 
The definition of wakaf based on economy is the moving wealth from consumption towards reproductive effort and investment in productive capital that can be produced and produce something that can be consumed in the future, either by individuals or a group. ${ }^{21}$ The definition of productive endowments terminology is the transformation of the management of natural endowments into wakaf professional management to improve or add to the benefits of endowments. ${ }^{22}$

The concept of productive endowments are essentially based on the dissatisfaction with the government (especially the Ministry of Religious Affairs) for the management of wakaf property conducted by the Nazhir. This dissatisfaction triggered the government to fix the paradigm of productive endowments, by establishing a law on endowments. If connected between the concept of "productive" with dissatisfaction over the government's management of wakaf made by the Nazhir, naturally became the definition of wakaf endowments professional management to improve or add to the benefits of endowments.

\section{The Setting Wakaf in Indonesia}

The genesis of Law No. 41 of 2004 on Endowments and PP No. 42 of 2006 regarding the implementation of the Wakaf Act is part of a renewed spirit and scope of the object endowments and management in order to bring the maximum benefit. Therefore, productive wakaf endowments are considered as a new paradigm in Indonesia. So since 2004, Indonesia has had an official body which manages the affairs of endowments. ${ }^{23}$ Based on Law No. 41 of 2004, the agency was renamed Indonesian Wakaf Board. The agency has the authority

\footnotetext{
${ }^{21}$ Mundzir Qahaf, Manajemen Wakaf Produktif., p. 58

${ }^{22}$ Jaih Mubarok, Wakaf Produktif ., p. 15

${ }^{23}$ Achmad Djunaidi, dkk., Paradigma Baru Wakaf di Indonesia, Cet. Ke-4 (Jakarta: Direktorat Pengembangan Zakat dan Wakaf Depag RI, 2007).
} 
to control all matters pertaining to the endowment. Indonesian Wakaf Board serve three kinds of endowments ministry namely (a) endowments movable property, (b) donations of land, and (c) cash wakaf. But in practice, the focus of this agency is on the donations of land and cash.

According Jaih Mubarok, there are at least two reasons for the formation of Wakaf Act: ${ }^{24}$

First, promote the general welfare. To achieve these objectives, the potential contained within religious institutions that have economic benefits need to be explored and developed. Among the measures is seen as strategic to promote the general welfare is increase the role of wakaf as a religious institution that was originally only serves as a means of worship and social, into institutions that have the economic power that is believed to promote the general welfare. Therefore, the potential exploration and development endowments utilization in accordance with Islamic principles is a necessity.

Second, the practice of wakaf that currently exist in society has not fully implemented in an orderly and efficient. One proof is among the wakaf property is not well maintained, neglected, even resorting to a third party unlawfully. Displacement and transfer of objects endowments into the hands of third parties occur because: (a) negligence or inability nazir in managing and developing the wakaf property; (b) the attitude of people who are less concerned or do not understand the status of wakaf property that should be protected as a medium to achieve common prosperity in accordance with the objectives, functions, and the allotment of endowments.

The Wakaf Act is a legal product in accordance with the dynamics and needs of the community, because it is a renewal and setting endowments comprehensively. It can be seen among others: (a) object diwakafkan, this law not only set the object

\footnotetext{
${ }^{24}$ Jaih Mubarok, Wakaf Produktif , p. 57
} 
is not moving, but moving objects such as money, securities, metals began, securities, vehicles, intellectual property rights, the right to lease, and other moving objects; (b) improvement requirements nazir, nazir for example, should be the mandate, this legislation also set the nazir who shaped the organization; (c) the establishment of new institutions in the field of perwakafan namely Indonesian Wakaf Board; (d) of this law emphasizes the empowerment and development of wakaf property that has high economic potential to improve the welfare of the community; (e) the provisions of the criminal and administrative sanctions for parties who deliberately abuse the wakaf property. ${ }^{25}$

In Article 1 of Law No. 41 of 2004, endowments defined as "a legal act wakif to separate and / or hand over part of their wealth either permanently or for a specified period in accordance with their interests for purposes of worship and / or general well-being according to sharia." Study contained in the wakaf Act is more comprehensive when compared to some of the legislation that went before in the field of endowments. ${ }^{26}$

Here are the things contained in the definition of Wakaf endowments according to the Act and its implementing regulations, that:

a. Wakaf is a legal act giving wakaf (wakif) a legal effect immediately after the release of property rights can be interpreted berwakaf wakif states make over the property at the time of wakaf.

b. The utilization of endowment addressed to property that is not solely for the sake of social and religious facilities, but also to promote kejesahteraan directed public by increasing the potential and economic benefits wakaf.

c. The utilization of wakaf property mentioned above can be implemented for a period or forever (eternal).

\footnotetext{
${ }^{25}$ Tata Fathurrohman, Wakaf dan Usaha Penanggulangan Kemiskinan ., p. 236

${ }^{26}$ Abdul Manan, Aneka Masalah Hukum Perdata dalam Islam di Indonesia (Jakarta: Kencana Prenada Media Group, 2006),
} 
This law besides endowment enhance existing regulations also set new problems, such as the management of wakaf property must be productive and clearly specified designation, such as to help the poor, entity formation endowments Indonesia, setting wakaf money, and materi- other materials required in accordance with contemporary developments.

\section{ASEAN Economic Community}

Jusuf Kalla said at the opening of the National Seminar on Opportunities and Challenges in Indonesia in the MEA at Hotel Borobudur, Friday, January 30, 2015, ${ }^{27}$ the ASEAN Economic Community (AEC) comes into force December 31, 2015, meaning that effective since 2016. The MEA is a community that wants to cooperate with the initial basis of free trade. That the free flow of goods, people and services so that there is no obstacle or borderless.

In 2003, the ASEAN leaders agreed that ASEAN Community should be formed in 2020. In 2007, the leaders reiterated their strong commitment to realize the ASEAN Community and speeding up the target time into 2015. The ASEAN Community consists of 10 countries, namely: Indonesia, Malaysia, Thailand, Philippines, Singapure, Brunei Darussalam, Vietnam, Laos, Myanmar (Burma) and Cambodia, the whole country is based on three pillars are linked to one another: Community security policy of ASEAN, ASEAN Economic Community and ASEAN Social Cultural Community. Thus, the leaders agreed to transform ASEAN into a region that is characterized by the free movement of goods, services, investment, skilled labor, and freer flow of capital.

Furthermore, the ASEAN Economic Community Blueprint drafted and ratified in 2007. The AEC Blueprint serves as a coherent master plan that directs the formation of

${ }^{27}$ http://www.wapresri.go.id/mea-kerjasama-dalam-persaingan, accessed at June 23, 2016. 
MEA. Blueprint identifies the characteristics and elements of MEA with a target and a clear deadline for the implementation of various measures and flexibility agreed to accommodate the interests of all member countries of ASEAN. Given the importance of external trade for the ASEAN Community and ASEAN as a whole needs to keep an open mind, MEA has the following main characteristics: (a) a single market and production base; (b) economic region with high competitiveness; (c) region of equitable economic development; and (d) a region fully integrated into the global economy. ${ }^{28}$ For that the Indonesian government has issued Presidential Instruction (Instruction) No. 11 of 2011 on the implementation of the AEC Blueprint commitments in an effort to prepare for the ASEAN free market. In the AEC Blueprint, there are 12 priority sectors that will be integrated by the government. The sector consists of seven sectors namely agro industrial goods, automotive, electronics, fisheries, rubber-based industry, woodbased industries, and textiles. Then the rest come from the five service sectors, namely air transport, health, tourism, logistics, and information technology. These sectors in the era of MEA will be implemented in the form of exemption flow of goods, services, investment, and labor.

MEA will establish ASEAN as a single market and production base to make ASEAN a more dynamic and competitive with the mechanisms and measures to strengthen the implementation of existing and new economic initiatives; accelerate regional integration in priority sectors; facilitating the movement of business, skilled labor and talents; and strengthen the institutional mechanisms of ASEAN. As a first step to realize the ASEAN Economic Community.

${ }^{28}$ Direktorat Jenderal Kerja Sama Perdagangan Internasional, Informasi Umum Masyarakat Ekonomi ASEAN, ASEAN Community in a Global Community of Nations (Jakarta: Kementerian Perdagangan RI, 2011),.p. 7 
Importance MEA is inseparable from the positive impact and benefits of the implementation of free trade in the region of the Southeast Asian region. Maybe this time the positive impact has not been so pronounced for MEA has just occurred, namely in 2015, but the magnitude of expected benefits will be felt in subsequent years. And below are some of the positive impacts or benefits of MEA, including: ${ }^{29}$

a. ASEAN Economic Community will encourage the flow of foreign investment into the country that will create a multiplier effect in the various sectors, especially in the field of economic development.

b. Market conditions that one (single market) makes the ease of formation of the joint venture (cooperation) between firms ASEAN region so that access to production materials more easily

c. Southeast Asian market is a huge market potential as well as promising with an area of about 4.5 million square kilometers and a total population of 600 million people

d. MEA provides an opportunity for ASEAN member countries in terms of increasing the speed of transfer of human resources and capital are two very important factors of production.

e. Especially for the field of technology, the implementation of the ASEAN Economic Community is creating a technology transfer from developed countries to developing countries in the Southeast Asia region.

That's five positive impacts or benefits of the implementation of MEAs which started in 2015, which co MEA itself in the form: ${ }^{30}$

a. Develop human resources and capacity building

${ }_{29}$ http://sukasosial.blogspot.com/2015/08/masyarakat-ekonomi-asean. html, accessed at June 23, 2016.

${ }^{30}$ Ibid. 
b. Recognition of professional qualifications

c. Closer consultation on macroeconomic and financial policies

d. Trade financing measures

e. Improve Infrastructure

f. The development of electronic transactions via E-Asean

g. Integrating the industry throughout the region to promote local resources

h. Increased involvement of the private sector to build the Asean economic community.

In principle, the MEA was formed on the basis of cooperation among ASEAN countries, where this cooperation is not a new thing because previously has done some in the form of bilateral cooperation. Era MEA is a form of competition in the field of economic development that is based on cooperation complementary or complementary.

Field of endowments, which has been promoting forms of productive endowments, which is productive endowments can not be removed from the economic values, especially of Islamic economics. MEA forms of cooperation led to a chance for the development of a modern wakaf in particular through the development of human resources managers of endowments (Nazhir), for example by doing a comparison of the form of management of wakaf in Indonesia with Singapore. Management of wakaf in Singapore is very modern and well ordered, but when viewed from mayoristas of the population is non-Muslim, but endowments run productively. So that the MEA era is a challenge in advancing the wakaf as a form of Islamic institutions were able to become a source of capital and investment for economic growth. 


\section{Cash Wakaf Development in AEC Era.}

Cash wakaf is done person, group, institution or legal entity in the form of cash, including in terms of money are securities, such as stocks and checks. Cash Wakaf is one of the Islamic economic instruments that potentially improve the socio-economic welfare. Endowments can have a good role to help resolve the problems of socio-economic if it could be managed professionally and productively. In addition, cash wakaf also serves as a strategic investment for eradicating poverty and addressing underdevelopment in the fields of economy, education, health, and so on. As one of the instruments of productive endowments, cash wakaf is a new thing in Indonesia.

Cash wakaf can also increase social investment and transform people's savings into capital, as well as help develop the social capital market. Development of cash wakaf in developed countries known as the charity sector. In an article mentioned, that this modern era of cash wakaf popularized by M.A Mannan by setting up an agency called Social Investment Bank Limited (SIBL) in Bangladesh. SIBL introducing certificates of cash wakaf (cash wakaf certificate) for the first time in the history of banking, SIBL raise funds from the rich to be managed and distributed profits to the poor management. Based on the experiences made by SIBL, according M.A Manan, wakaf investment money can be made on a variety of social investment activities that have long benefits. In addition SIBL investment activities also create a lasting social capital and help the development of programs that strengthen family values and encourage the formation of social capital base and that are important to the welfare of society. ${ }^{31}$

${ }^{31}$ Rozalinda, Pengelolaan Wakaf Uang: Studi Kasuspada Tabungan Wakaf Indonesia (TWI) Dompet Dhuafa Republika, Disertasi, Sekolah Pascasarjana Universitas Syarif Hidayatullah, Jakarta, 2010, p. 6. 
Wakaf has been understood by the public merely wakaf lands, so that ultimately the Indonesian Ulema Council (MUI) issued a fatwa lawful for cash wakaf on May 11, 2002. After considering the Qur'an, hadith, and ultimately scholarly opinion Fatma Commission MUI cash wakaf in its decision that:

a. Cash Wakaf (Endowments Cash/ Wakaf al-nuqud) are endowments that a person, group, institution or legal entity in the form of cash.

b. Included in the definition of Cash is securities.

c. Cash wakaf should only be channeled and used for things that are allowed in syar'i

d. The principal amount in cash wakaf must be guaranteed sustainability may not be sold, assigned, or inherited ${ }^{32}$

Cash Wakaf is a legal product, namely Law No. 41 of 2004 challenged Wakaf. Article 16 of the Act, states that: The properties endowments consist of immovable and movable goods. While the cash wakaf included in the scope of moving objects.

Wakaf money management involves three main parties: (a) wakif, (b) Nazhir that can also act as an investment manager, and (c) mauquf'alaih (beneficiary) are distributed to the parties entitled. Management of wakaf money professionally marked by empowering society as productive potential. Professionalism may include aspects of management, HR Nazhir, business partnership and political will of governments in full. ${ }^{33}$

On the issue of management of wakaf money, according Uswatun Hasanah, nazhirnya can not be equated with Nazhir wakaf lands. Nazhir wakaf lands can be done by a group of persons or legal entities, while the cash wakaf should be managed by a professional institution with the following criteria: (a) have rapid access to wakif, (b) have kemanpuan investing

\footnotetext{
${ }^{32}$ Keputusan Fatwa Komisi Fatwa Majelis Ulama Indonesia tentang Wakaf Uang.

${ }^{33}$ Jait Mubarok, op cit., p. 22.
} 
wakaf property, (c) have the ability to account administration beneficiary, (d) have the ability distribution of wakaf property investment, (e) have credibility in the community and operates based on the legislation that is so easily monitored and controlled. ${ }^{34}$

The opening of Wakaf Board Indonesia (BWI) as an independent agency tasked to develop perwakafan in Indonesia, where membership is appointed directly by the President of the Republic of Indonesia through Presidential Decree (Decree) No. 75/ M of 2007, has a strategic function as a caretaker mandate of Law Wakaf deserve our syurkuri and mutual support. Especially today, there are 5 LKS-PWU which was inaugurated by the Minister of Religious Affairs as Minister of Religion birth regulation No. 4 of 2009, the Bank Muamalat, Bank Syariah Mandiri, Bank BNI Syariah, Bank DKI Syariah and Bank Mega Syariah. People who wanted to invest the afterlife to get the reward that continues to flow, may be donating funds to BWI or Wakaf Fund Management through Islamic banks that have been appointed. In this case the Bank is not only as the recipient and distributor of endowment funds, but also as manager of the property (funds), develop, and distribute the funds in accordance with the intended purposes wakif or bank.

Endowments in cash received by the Bank as donations, which will be acceptance of such donations will get the highest profit rate offered by the Bank. So that the quantity remains intact and only the profits are spent for the benefit of wakaf. In this case wakif will receive a certificate of cash wakaf (cash certificate waqh), which indicates that there has been perwakafan. Cash Wakaf certificate is a financing alternative that is social and business as well as the active participation of all citizens of a rich country for a variety of happiness with

${ }^{34}$ Uswatun Hasanah, 2004, Permasalahan Penerapan Wakaf Tunai, Modal No. 21/IIJuni, p. 5. 
his brother in the enjoyment of education, health and other social welfare well. Dangan not too drape themselves with the government's budget and foreign loans, it is expected that the implementation of these instruments Cash Wakat certificate to be an alternative source of funding social. ${ }^{35}$

Therefore, in order to develop more broadly, cash wakaf should get more attention to finance social projects through empowerment endowments immovable property which has been a burden. Or it could be through distribution to the development of institutions of education, health, social services and economic empowerment through empowerment of small and medium enterprises. As one of the efforts that the distribution of funds in the form of productive financing mobilized to the real sector, namely by providing micro-credit through the mechanism of the Collective Investment Contract (KIK) sort of Shariah funds collected through the Cash Wakaf Certificate to the medium and small communities that have business opportunities and little by little rise out of poverty and deterioration as a result of the protracted crisis.

The economic crisis that hit Indonesia still have an impact on the social conditions of society. The collapse of basic building the nation's economy is the key issue to improve the local economy. The economic actors who felt I knew the adverse effects of these conditions are the small and medium entrepreneurs. For the development and empowerment include: (a) Prioritize the promotion and development of SMEs that use raw materials derived from natural resources and industry, (b) Giving greater opportunities to professional agencies banking, (c) Training for SMEs in terms of the ability of the process technology and production, (d) Helping SMEs marketing both

${ }^{35}$ Proyek Peningkatan Zakat dan Wakaf Direktorat Jenderal Bimas Islam dan Penyelenggaraan Haji, Fiqih Wakaf (Jakarta: Proyek Peningkatan Zakat dan Wakaf Direktorat Jenderal Bimas Islam dan Penyelenggaraan Haji, 2003), p. 96. 
inside and outside the country, (e) Development of infrastructure to support the economic empowerment of the people. ${ }^{36}$

To promote SMEs with the Islamic system is very influential in the economic perbagaikan people, especially for SME businesses. Therefore, in order to implement the system of Islamic (Sharia) in the community, requires a strategy and seriousness to raiser strength. In Indonesia, SMEs have a strategic role and contribute greatly to the national economy by contributing 53.3\% of total GDP (Gross Domestic Product). The number of SMEs in Indonesia reached around 56.2 million units and capable of absorbing $97.2 \%$ of the workforce of the total labor force available, ${ }^{37}$ the strengthening of SMEs are also the focus of the government in the face of the MEA. Many challenges faced by SMEs in the era of MEA's, among others: mindset of Indonesian society still tends to consume products or services from abroad than in the country, still weak infraktruktur as access tranfortasi that cause economic costs become higher, the limitations of SMEs in utilizing technology, the number of SMEs that do not have a business plan that is not yet mature, and most importantly, SMEs face financial constraints in the development of the business.

So work movement increase cash wakaf is necessary, where models of cash wakaf through the Certificate of Endowments Cash felt necessary and urgent as alternative instruments that can fill the deficiencies in sectors concerning the improvement of the welfare of the community, particularly in this era of MEA this demanding government's readiness to perform various strategy plans in the face of MEA, including: strengthening the competitiveness of the economy, strengthening the ACI program (Aku Cinta Indonesia) which is one of the movement

${ }^{36}$ Direktorat Jenderal Pemberdayaan Wakaf, Pedoman Pengelolaan Wakaf Tunai (Jakarta: Direktorat Jenderal Pemberdayaan Wakaf, 2007), p. 98.

37 http: // zahirac counting .com/id/blog/tantangan-ukm-dalammenghadapi-mea, accessed at June 23, 2016. 
'Nation Branding' part of the development of creative economy, including in the Presidential Decree No. 6, 2009 the program contains the Creative Economy for the 27 State and Local Government Ministry, repair infrastructure, the increase of the quality in human resources, as well as strengthening the growth of SMEs.

\section{Conclusion}

ASEAN Economic Community will establish ASEAN as a single production base that makes ASEAN a more dynamic and competitive with the mechanisms and measures to strengthen the priority sectors, facilitating the movement of business, skilled labor, and to the strengthening of institutional mechanisms of ASEAN. Endowments in cash as a religious institution, should be medern dikelolaan so as to maximize its function become one of the financial instruments that can strengthen economic growth is through channeling funds to the community, such as helping the growth of SMEs, since SMEs are also to be one focus of the government in the face of the MEA. 


\section{REFERENCE}

\section{Book}

Abdullah al-Kabisi, Muhammad Abid, Hukum Wakaf: Kajian Kontemporer Pertama dan Terlengkeap Tentang Fungsi dan Pengelolaan Wakaf serta Penyelesaian atas Sengketa Wakaf, Jakarta: Penerbit Iiman kerja sama dengan Dompet Dhuafa Republika, 2004.

Anshori, Abdul Ghofur dan Yulkarnain Harahab, Hukum Islam Dinamika dan Perkembangannya di Indonesia, Yogyakarta: Kreasi Total Media, 2008.

Basyir, Ahmad Azhar, Hukum Islam tentang Wakaf, Ijarah, Syirkah, Bandung: Al-Ma'arif, 1987.

Daud Ali, Mohammad, Sistem Ekonomi Islam Zakat dan Wakaf, Jakarta: UI-Press, 2012.

Direktorat Jenderal Kerja Sama Perdagangan Internasional, Informasi Umum Masyarakat Ekonomi ASEAN, ASEAN Community in a Global Community of Nations, Jakarta: Kementerian Perdagangan RI, 2011.

Direktorat Jenderal Pemberdayaan Wakaf, Pedoman Pengelolaan Wakaf Tunai, Jakarta: Direktorat Jenderal Pemberdayaan Wakaf, 2007.

Djadmika, Rachmad, Hukum Perwakafan Tanah Milik di Indonesia, Bandung: t.p., 1983.

Djunaidi, Achmad, dkk., Paradigma Baru Wakaf di Indonesia, Cet. Ke-4, Jakarta: Direktorat Pengembangan Zakat dan Wakaf Depag RI, 2007.

Manan, Abdul, Aneka Masalab Perdata Islam di Indonesia, Jakarta: Kencana Prenada Media Group, 2006.

Mubarok, Jaih, Wakaf Produktif, Bandung: Simbiosa Rekatama Media, 2008. 
Proyek Peningkatan Zakat dan Wakaf Direktorat Jenderal Bimas Islam dan Penyelenggaraan Haji, Fiqib Wakaf, Jakarta: Proyek Peningkatan Zakat dan Wakaf Direktorat Jenderal Bimas Islam dan Penyelenggaraan Haji, 2003.

Rofiq, Ahmad, Hukum Islam di Indonesia, Jakarta: Raja Grafindo Persada, 1997.

Quhar, Munzir, Manajemen Wakaf Produktif, Jakarta: Khalifa, 2004.

\section{Journal}

Hasanah, Uswatun, Permasalahan Penerapan Wakaf Tunai, in Modal, No. 21/II, Juni 2004.

M.S. Rahaman, Chowdury, Problems of Waqf Administration and Proposals for Improvement: a Study in Malaysia, in Journal of Internet Banking and Commerce, Vol. 17, No. 1, April 2012.

\section{Dissertation}

Hasanah, Uswatun, Peranan Wakaf dalam Mewujudkan Kesejabteraan Sosial (Studi Kasus Pengelolaan Wakaf di Jakarta Selatan), Disertasi, Program Pascasarjana Institut Agama Islam Negeri (IAIN) Syarif Hidayatullah, Jakarta, 2007.

Fathurrohman, Tata, Wakaf dan Usaha Penanggulangan Kemiskinan Tinjauan Hukum Islam dan Perundang-undangan Indonesia, Disertasi, Program Pascasarjana, Universitas Indonesia, Jakarta, 2006.

Rozalinda, Pengelolaan Wakaf Uang: Studi Kasus pada Tabungan Wakaf Indonesia (TWI) Dompet Dhuafa Republika, Disertasi, Sekolah Pascasarjana Universitas Syarif Hidayatullah, Jakarta, 2010. 
Onny Medaline

\section{Internet}

http://simbi.kemenag.go.id/siwak/index.php.

http://www.wapresri.go.id/mea-kerjasama-dalam-persaingan. http:/ / sukasosial.blogspot.com/2015/08/masyarakatekonomi-asean.html.

http:/ / zahiraccounting.com/id/blog/tantangan-ukm-dalammenghadapi-mea. 